\title{
Meningkatkan Minat Baca Pada Anak-Anak Kampung Air Asin Pangkalpinang Di Masa Pandemi Covid-19 Melalui Program Pondok Baca
}

\author{
Trisna Amelia Putri ${ }^{1}$, Achmad Syahrial ${ }^{2}$, Edwir Fyanurdin ${ }^{3}$, Heni Yuniarti ${ }^{4}$, Irina Weni \\ Merkuri $^{5}$, Yesi Okta Apriyanti ${ }^{6}$
}

${ }^{1}$ Universitas Muhamadiyah Bangka Belitung

${ }^{2}$ Universitas Muhamadiyah Bangka Belitung

${ }^{3}$ Universitas Muhamadiyah Bangka Belitung

${ }^{4}$ Universitas Muhamadiyah Bangka Belitung

${ }^{5}$ Universitas Muhamadiyah Bangka Belitung

${ }^{6}$ Universitas Muhamadiyah Bangka Belitung

\section{Info Artikel :}

Diterima 28 Agustus 2021

Direvisi 21 september, 2021

Dipublikasikan 21 oktober 2021

\section{Kata Kunci: \\ Pondok Baca,}

Anak-anak,

\section{Keywords:}

Reading Hut, Children

\begin{abstract}
ABSTRAK
Artikel ini bertujuan untuk meningkatkan Minat Baca Pada Anak-Anak Kampung Air Asin Pangkalpinang Di Masa Pandemi Covid-19. Metode yang digunakan adalah observasi dan dokumentasi. Keberhasilan yang di dapatkan dari program pondok baca ini salah satunya dapat membantu anak-anak Kampung Air Asin Pangkalpinang di masa pandemi covid-19 ini agar memudahkan mereka menggunakan semua sarana dan prasarana yang tersedia untuk menunjang belajar. Program ini berdampak positif bagi anakanak, orangtua maupun para guru disekolahnya untuk mengatasi hambatanhambatan yang dihadapi.
\end{abstract}

\begin{abstract}
This article aims to increase reading interest in the children of Pangkalpinang Saltwater Village during the Covid-19 Pandemic. The methods used are observation and documentation. One of the successes that have been gained from the pondok Baca program is to help the children of Kampung Air Asin Pangkalpinang during the Covid19 pandemic to make it easier for them to use all available facilities and infrastructure to support learning. This program has a positive impact on children, parents and teachers in their schools to overcome related obstacles
\end{abstract}

This is an open access article distributed under the Creative Commons Attribution License, which permits unrestricted use, distribution, and reproduction in any medium, provided the which permits unrestricted use, distribution, and

Koresponden:

Trisna amelia putri

putryamelia445@gmail.com

\section{Pendahuluan}

Usaha-usaha yang dilakukan sebagai proses pembaharuan dalam bidang pendidikan serta pengajaran dalam upaya memperbaiki kualitas masyarakat Indonesia yang sudah lama terombang-ambing oleh para penjajah akan segera dilakukan setelah Indonesia memproklamirkan kemerdekaannya yaitu pada tanggal 17 Agustus 1945. Mengenai pendidikan Agama yang ada di sekolah, saat ini pemerintah terlihat mulai memberikan perhatian lebih setelah sekian lama waktu penjajahan, hal tersebut karena tidak ada ruang untuk pendidikan Agama di dalam sekolah negeri. Menteri Pendidikan, Pengajaran, dan Kebudayan yaitu Ki Hajar Dewantara pada saat itu dengan lantang dan tegasnya mengatakan tepatnya di sebuah tempat yaitu alun-alun Yogyakarta bahwa pengajaran pendidikan Agama sangat dibutuhkan di sekolah-sekolah milik pemerintah (Kosim, 2014). Pendidikan Islam di Indonesia sebenarnya sudah ada sejak lama. Islam masuk ke Indonesia dengan berbagai kultur atau budaya, antara lain adalah perkawinan, perdagangan, dan juga pendidikan. Pendidikan Islam dapat diartikan sebagai kegiatan belajar mengajar yang target pokoknya 
adalah bertujuan untuk memberikan suatu pengetahuan tentang Islam serta dapat menanamkan perilaku dan sikap beragama yang ditujukan kepada peserta didiknya (Supandi, 2017).

Pada Pada zaman orde lama, secara spesifik pendidikan Islam belum diperhatikan oleh pemerintah, dikarenakan zaman orde lama di Indonesia berada dalam keadaan lemah dan masih banyak keperluan lain yang harus dipelajari untuk mengembangkan berbagai aspek, mulai dari struktur kenegaraan yang baru saja dibangun, kemudian Negara Indonesia masih membutuhkan dukungan dan komunikasi dengan Negara lain untuk menjalin suatu hubugan kerja sama dalam bidang apapun, kemudian Negara Indonesia masih membutuhkan banyak modal untuk membangun Negara ini. Sehingga banyak sekali permasalahanpermasalahan yang kemudian muncul, seperti permasalahan tentang ideologis politik dan dari beberapa politik Islam elite yang menimbulkan pihak pemerintah merasa curiga dan menimbulkan perasaan tidak suka atau tidak senang pada umat Muslim, keadaan ini terus menerus terjadi dan terlihat seperti sedang terlibat perang dingin antara pihak pemerintah pada masa orde lama dengan tokoh dan politik Islam elit yang selanjutnya berdampak pada tidak diperhatikannya pendidikan Islam di Indonesia.

Pada era Orde Baru inilah Soeharto memiliki kepemimpinan yang militeristik dan sangat kuat. Pada masa ini rakyat sipil dimatikan suara beserta perannya. Sederhana saja pada masa Soeharto pada kelompok tertentu diharuskan memberikan suara mereka kepada golongan karya yang mempunyai relasi dengan pemerintah. Adanya kewajiban tersebut tak heran selama diadakannya pemilu sebanyak empat kali, perolehan suara yang terbanyak yang akan terus menjadi memimpin. Sedangkan suara yang lain yang ingin membela dan menegakkan syari'at Islam sebagai landasan negara ini nyaris tidak terdengar (Syamsuddin \& Fatkhan, 2010). Pada dasarnya semangat pekembangan hukum Islam di Indonesia ini menggantungkan harapannya kepada pemerintahan Orde Baru. Harapan tersebut timbul setidaknya dikarenakan adanya partisipasi yang diberikan oleh umat Islam yang cukup besar dalam merobohkan pemerintahan orde lama. Akan tetapi pada kenyataannya adalah keinginan serta harapan umat muslim dalam kegiatan memajukan dan mengkonversikan beberapa nilai hukum Islam dalam perundang-undangan tersebut malah mengalami permasalahan yang bisa dibilang cukup besar, karena kegiatan tersebut berlawanan dengan strategi pada pembangunan yang dikuasai para penguasa di pemerintahan Orde Baru ini. Pada saat Orde Baru kali ini juga peranan partai politik direndahkan, termasuk pembahasan-pembahasan mengenai masalah yang berkenaan dengan ideologi yang selain ideologi Pancasila maka dilarang, dan terutama ideologi yang sifatnya adalah keagamaan.(Alidar, 2012).

Reformasi ini merupakan suatu perubahan yang mencolok untuk melakukan perbaikan baik di bidang politik, sosial, ekonomi, maupun didang keagamaan dalam kehidupan masyarakat atau negara. Sehubungan dengan reformasi dan juga globalisasi pendidikan adalah salah satu harapan di bidang ekonomi dan dapat digunakan sebagai penebuhan kebutuhab pasar global. Dalam pandangan Islam pendidikan merupakan bagian dari tugas manusia sebagaikhalifah yang harus dilakukan dengan penuh tanggungjawab, dan pertanggungjawaban tersebut dapat diajukan atau dituntut ketika ada suatu peraturan serta pedoman pelaksanaannya. Penjelasan tentang pendidikan Islam ini melahirkan adanya suatu penekanan atas makna dari pendidikan pengukuhan akhlak, penerapan metode, dan pendekatan yang memiliki sifat teoritis dan praktis ke arah peningkatan dan perbaikan sikap mental yang menggabungkan antara keimanan dan amal sholih yang melekat pada individu dam masyarakat luas. Pendidikan Islam ini merupakan sekumpulan teori yang tersusun dari al-Qur'an dan Hadits (Dacholfany, 2015)

\section{Metode}

Penelitian ini menggunakan metode kualitatif, Strauss dan Corbin (2007:1), penelitian kualitatif ialah penelitian untuk mengamati kehidupan dalam ruang lingkup masyarakat, sejarah, perilaku, fungsi organisasi, gerakan sosial atau hubungan persaudaraan. Sedangkan Bogdan dan Taylor (1992:21), mengatakan bahwa penelitian kualitatif ini merupakan penelitian yang dapat menghasilkan perolehan data deskrtiptif yang biasanya berupa lisan, tulisan, dang dari perilaku seseorang yang diamati. Dengan menggunakanbentuk library research atau penelitian kepustakaan (Nugrahani, 2014). Penelitian kepustakaan ialah sebuah studi di mana dalam pengumpulan data dan informasinya berasal dari buku, majalah, dokumen, jurnal, buku sejarah, dan lain-lain. Penelitian kepustakaan ini diambil dari beberapa referensi buku dan jurnal tentang sejarah pendidikan Islam pada zaman orde lama, orde baru dan reformasi. Fokus penelitian ini adalah bagaimana kondisi pendidikan Islam yang terjadi pada masa tersebut. Sari, M., \& Asmendri, A. (2020). Penelitian Kepustakaan (Library Research) dalam Penelitian Pendidikan (Sari \& Asmendri, 2020) 


\section{Hasil Dan Pembahasan}

A. Definisi Pendidikan Islam

Dalam bahasa yunani pendidikan berasal dari kata padegogik yang berarti kepandaian dalam membimbing anak. Sedangkan menurut Kamus Besar Bahasa Indonesia (KBBI) pendidikan merupakan pemberian ajaran mengenai adab dan kepandaian dalam pikiran. Pendidikan secara umum merupakan sebuah metode dalam pembaruan sifat, sikap dan perilaku individu atau masyarakat dalam upaya pendewasaan melalui pengajaran, jalannya dalam berperilaku, dan cara dalam mendidik individu maupun kelompok. Menurut Ki Hajar Dewantara, pendidikan merupakan sebuah usaha yang bertujuan untuk mengembangkan kesempurnaan kehidupan.

Dari definisi-definisi tentang pendidikan tersebut dapat disimpulkan bahwa pendidikan merupakan sebuah usaha untuk membimbing anak sejak dalam kandungan hingga dewasa dalam jasmani dan rohani (Nurkholis, 2013). Dalam pendidikan pun berusaha dalam memberi arahan seluruh kemampuan peserta didik ataupun siswa secara maksimal yang bertujuan untuk mewujudkan suatu kepribadian yang paripurna pada setiap individu. Dalam dunia pendidikan berharap besar terhadap peserta didik yang membawa kualitas hidup yang sebaik-baiknya (Yusuf, 2018).

Pendidikan merupakan sebuah proses yang mencakup 3 bagian, diri sendiri, masyarakat dan seluruh realitas. Dalam upaya meningkatkan kualitas dan kapasitas individu. Pendidikan sangat berperan penting dalam jalannya kehidupan. Sehingga pendidikan tidak hanya tentang sekolah saja tetapi sampai dalam jalannya kehidupan seseorang (Musanna, 2017). Tetapi lebih dari sebuah jalannya transfer ilmu, nilai dan pembentukan sikap sifat dengan segala yang ingin dituju. Oleh karena itu, dalam sekolah atau pengajaran tersebut lebih berperan utama pada pembentukan kepribadian atau bidang-bidang tertentu. Pendidikan sendiri merupakan sebuah jalan yang sangat dibutuhkan dalam perkembangan individu bahkan masyarakat.

Pendidikan memiliki dua hal penting yakni aspek kognitif (berpikir) dan afektif (merasa). Sebagai contoh, saat kita belajar tidak hanya mengandalkan pikiran saja, tetapi juga komponen-komponen lain mengenai dengan perasaann seperti suka, gembira, dan sebagainya. Pokok pendidikan menurut Ki Hajar dewantara adalah membebaskan atau membiarkan manusia. Sehingga terbukti bahwa pendidikan tidak hanya mengandalkan dalam hal kognitif saja, tetapi dapat membahas lebih luas.

Sedangkan pendidikan Islam merupakan penciptaan perilaku mukmin atau perubahan sifat, sikap dan perilaku sesuai dengan ajaran Islam. Pendidikan dalam Islam memang bertujuan untuk menciptakan perilaku umat muslim seutuhnya, menumbuhkan segala kemampuan manusia baik jasmani dan rohani. Pendidikan islam merupakan serangkaian kegiatan yang dilaksanakan dengan sistematis untuk menumbuhkan kemampuan pada setiap anak berlandaskan syariat agama Islam (Awwaliyah \& Hasan, 2018)

Pada dasarnya pendidikan merupakan penghubung dalam proses membimbing dan menumbuhkan kemampuan-kemampuan kemanusiaan yang baik. Selain itu, pendidikan menjadi pengantar umat manusia menuju peradaban yang lebih agung atau tinggi berdasarkan pada keseimbangan jalinan manusia, lingkungan, dan sang pencipta. Pendidikan merupakan suatu bidang yang didalamnya mengaitkan dengan kehidupan manusia. Tujuan secara umum pendidikan islam adalah menjadikan kepribadian setiap mukmin memiliki daya pikir yang maju, bersedia dalam melegalkan setiap kebenaran ilmunya itu, dan ahli mengimplementasikan ilmu yang dimilikinya. Tujuan pendidikan Islam dapat terwujud jika dijalankan sesuai dasar-dasar yang benar yaitu Al Quran dan Hadist (R. Hidayat, 2016). Berdasarkan pendapat beberapa ahli tentang definisi pendidikan Islam :

1. Drs. Ahmad D. Marimba

Pendidikan Islam merupakan tuntunan jasmani dan rohani berlandaskan kaidah-kaidah Islam menuju terciptanya perilaku yang pokok atau utama menurut syariat Islam. Dengan definisi lain, perilaku yang utama berarti perilaku muslim. Perilaku muslim yakni mempunyai nilai yang terkandung dalam agama islam dan senantiasa bertanggungjawab sesuai dengan nilai-nilai Islam.

2. Musthafa Al-Ghulayani

Pendidikan Islam merupakan menegakkan sifat dan sikap yang mulia didalam jiwa setiap anak dalam pertumbuhannya diberikan nasihat-nasihat dan petunjuk sehingga akhlak menjadi peran utama guna terwujudnya memiliki rasa cinta bekerja agar bermanfaat pada tanah air.

3. Drs. Burlian Shomad 
Pendidikan Islam merupakan pendidikan yang memiliki tujuan membentuk setiap orang menjadi manusia yang berciri khas berderajat tinggi menurut Allah SWT dan dalam kandungan pendidikannya guna mewujudkan tujuan tersebut.

Dari beberapa pendapat yang sudah disampaikan oleh para pakar dapat disimpulkan bahwa pendidikan Islam merupakan tuntunan yang harus dikerjakan oleh orang dewasa kepada anak terdidik dalam masa pertumbuhan guna terwujudnya perilaku muslim (Azis, 2019). Pendidikan sebagai upaya membimbing dan membentuk pribadi setiap individu, jasmani dan rohani tetapi berlangsung secara bertahap (Rahman, 2012).

Pendidikan Islam merupakan suatu proses dalam menuntun diri yang memuat aspek akal, jasmani, dan hati yang bertujuan membina perilaku muslim yang berkaitan dengan nilai-nilai islam agar setiap individu dapat hidup guna dapat menjalankan tugasnya dimuka bumi sebagai khalifah (T. Hidayat et al., 2018).

B. Keadaan Pendidikan Islam pada Zaman Orde Lama, Baru, dan Reformasi

Orde lama merupakan orde yang terjadi pada periode pemerintahan Presiden Ir. Soekarno tahun 1945 sampai tahun 1968. Ir. Soekarno memerintah Negara Indonesia dengan menggunakan konstitusi Undang-Undang Dasar Sementara Republik Indonesia 1950. Pada saat awal kemerdekaan. Pemerintah Republik Indonesia sudah mengadakan pembinaan mengenai pendidikan Islam. Perkembangan pendidikan sangat terkait dengan peran Departemen Agama yang mulai resmi berdiri 3 Januari 1946 (MUDZAKKIR, 2015). Dalam pelaksanaan pembinaan pendidikan agama Islam ini dilakukan dengan cara tradisi formal yang diamanatkan kepada Departemen Pendidikan dan Kebudayaan serta Departemen Agama. "Pendidikan Agama Islam akan diatur oleh pemerintah mulai Desember 1946 di sekolah-sekolah umum, sebelum pendidikan agama yang digunakan sebagai pengganti pendidikan budi pekerti di mana sudah ada dari zaman Jepang di beberapa daerah".

Sebelum kemerdekan Indonesia, sebenarnya Departemen agama sudah ada. Namun sudah ada sejak zaman penjajahan Belanda dengan nama Kantoor voor Inlandshe Zaken, kemudian di zaman penjajahan Jepang dinamai Shukuma, Kemudian, Indonesia merdeka pada tanggal 3 Januari 1946 berubah menjadi Kementrian Agama. Pada tahun 1945 setelah Indonesia merdeka dibentuklah kepanitiaan perumusan kebijakan pendidikan dengan pemaparan berupa model pendidikan Islam lama dan model baru, mengatakan: "Pada hakikatnya madrasah dan pesantren merupakan sumber pendidikan dan alat untuk mencerdaskan rakyat, yang sudah mendarah daging pada rakyat Indonesia, sebaiknya madrasah/pesantren memperoleh perhatian nyata berupa bantuan materiil dan berupa tuntunan dari pemerintah, karena lembaga tersebut meyediakan pendidikan agama dan termasuk dalam Departemen Agama".

Walaupun banyak yang menyambutnya dengan baik akan sumbangan materiil dan pemberian fasilitas oleh kebijakan Pemerintahan Orde lama, akan tetapi terdapat beberapa masyarakat yang tidak menyetujui. Setelah pemerintah colonial Belanda beberapa waktu lalu telah memojokkannya. Kebijakan Pemerintah pada masa Orde Lama ini dianggap Oase untuk melakukan pengembangan terhadap pendidikan Islam di Indonesia. Kebijakan pemerintah Orde Lama ini merupakan awal mula dari munculnya pendidikan Islam yang terjadi secara menyeluruh dari kelembagaan (madrasah) maupun non lembaga (masjid dan surau yang digunakan sebagai tempat untuk mengaji). Madrasah di Indonesia yang dikelola oleh suatu organisasi sosial kemasyarakatan banyak dipengaruhi oleh orientasi organisasinya (Romlah, 2016) Peran yang sangat berpengaruhterhadap perkembangan madrasah yang dimiliki Departemen Agama pada masa Orde Lama adalah semangat yang tinggi dan kegigihan yang sangat intens dalam mempertaruhkankan politik pendidikan Islam di Indonesia. Mengajarkan pendidikan agama di sekolah-sekolah menjadi salah satu cara untuk penyesuaian Departemen Agama selain pada peluasan madrasah itu sendiri. Usaha tersebut secara khusus diatasi oleh satuan yang mengelola pendidikan Agama.

Departemen Agama juga menyarankan agar pesantren yang keadaannya masih tradisional untuk dimajukan menjadi sebuah madrasah dan tetap diatur dengan konsep klasikal, dan menggunakan kurikulum yang tetap dan mengikutsertakan mata pelajaran umum di samping mata pelajaran agama. Imbauan Departemen Agama ini menjadi sebuah kesempatan bagi umat Islam dalam rangka mendirikan lembaga pendidikan Islam. Dari beberapa contoh perkembangan madrasah yang sangat kentara saat Orde Lama ini adalah dikembangkannya (PGA) Pendidikan Guru Agama dan Pendidikan Hakim Islam Negeri. Keduanya menjadi bukti atas perkembangan yang sangan penting karena madrasah dilibatkan dalam mencetak tenaga professional bidang keagamaan, selain mempersiapkan tenaga yang bersedia untuk mengembangkan madrasah. Madrasah ini sudah tersebar hampir di seluruh kota-kota di Indonesia pada tahun 60-an, dan untuk madrasah Ibtida'iyah ini dilaporkan mencapai 13.057 unit, Madrasah Tsanawiyah 776 unit, serta Madrasah 'Aliyah mencapai 1.188 unit pendidikan. 
Oleh karena itu, pada masa rezim Orde Lama ini Departemen Agama yang akan turun tangan langsung untuk membawahi madrasah dengan bidang khusus yang akan menangani. Dalam hal ini, pendiri madrasah diberi banyak kesempatan untuk membangun dan mengembangkan madrasah. (Sudarmono, 2020).

Masa Orde Baru diawali dengan adanya Supersemar atau biasa disebut dengan Surat Perintah Sebelas Maret yang terjadi sekitar Tahun 1966, hal ini merupakan awal mula terjadinya pegantian kekuasaan Ir.Soekarno (pemerintahan lama) kepada Soeharto (pemerintahan baru). Pergantian tersebut memberikan efek pada perubahan antara strategi bidang politik dan juga kebijakan pada pendidikan tingkat nasional. Awal masa Orde Baru, pemerintah sukses mengalihkan perhatian mengenai bidang pendidikan dari sebuah perselisihan antara ideologis politis kepada orientasi praktis. Pada saat itu pendidikan ditempatkan pada bagian dari sebuah strategi kebudayaan, yang menjadikan pendidikan sebagai alat untuk membentuk manusia modern dan mandiri dari kedaulatan dan bersikap menyukai ilmu serta tekhnologi. Dalam hal ini, pendidikan diatur agar menghasilkan kekuatan sehingga dapat membangkitkan laju industri yang merupakan suatu program pemerintah.

Orde baru ini pada dasarnya merupakan sebuah interelasi total terhadap orde lama di mana orde lama ini didominasi oleh PKI yang disinyalir bertentangan dengan pancasila. Orde baru diharapkan membawa wajah baru pada kebijakan pendidikan Islam dikarenakan telah mengalihkan efek dari paham komunisme menjadi purifikasi Pancasila yang melalui perencanaan pembangunan nasional secara kontinu. Sehingga Orde Baru sering dikatakan sebagai Orde Pembangunan dan juga Orde Konstitusional. Yaitu memiliki tujuan untuk mewujudkan seorang manusia yang sebaik-baiknya serta mengimbangkan antara jasmani dan rohani untuk menjadikan kehidupan yang positif. Dengan peningkatan pembangunan yang semakin tinggi, maka diharapkan kepercayaan kepada Tuhan akan semakin baik, yaitu baik dalam kehidupan masing-masing individu ataupun dalam kehidupan sosial. Untuk itu diupayakan agar pembangunan sarana-sarana yang dibutuhkan dalam pengembangan keagamaan termasuk pada pendidikan Agama Islam untuk didaftarkan di dalam kurikulum pada semua jenjang pendidikan dari Sekolah Dasar sampai Perguruan Tinggi (Yuningsih, 2015).

Respon masyarakat muslim sangat dirasakan pada masa pemerintahan Orde Baru ini yang berhubungan dengan Inpres 15/1974 dan Kepres 34/1972, kemudian langkah yang diambil oleh pemerintahan Orde Baru adalah sebuah kebijakan mengenai madrasah. Yaitu untuk membina kualitas pendidikan madrasah. Sehingga pada 24 Maret, SKB atau Surat Keputusan Bersama ini ditandatangani oleh tiga menteri pada tahun 1975. Surat Keputusan Bersama ini sukses menjaga eksistensi madrasah dengan melibatkannya dalam sistem pendidikan nasional, dengan memberi ruang pergerakan terhadap lulusan dari madrasah sebagai bandingan tambahan ilmu umum sebanyak 70\% dari kurikulum dan pelaksanaannya yang selalu ditangani oleh Departemen Agama. Dari ketegangan yang terjadi ketika keluarnya SKB tersebut, tampak ada bayangan kemenangan Departemen Agama sebagai perantara aspirasi atau harapan umat. Akan tetapi, jika diingat kembali bahwa ada salah satu dari rencana/strategi kebudayaan yang digunakan pada masa Orde Baru adalah merubah bagian-bagian masyarakat dalam suatu kesatuan, maka sebenarnya SKB adalah sebuah kemenangan Departemen Agama sebagai anggota pemerintah. Hal tersebut berarti masyarakat muslim yang tergabung dalam masyarakat bangsa, untuk meningkatkan penguasaan mereka maka Surat Keputusan Bersama (SKB) ini dapat dijadikan sebagai alat pengontrolnya. Apalagi dilihat bahwa Surat Keputusan Bersama (SKB) ini diikuti inpres (sekolah kecil) di mana inpres ini terbukti mampu menghidupkan ribuan madrasah dari bantuan pemerintah dalam merehab bangunannya. Ditambah dengan adanya subsidi yang diberikan kepada madrasah menjadikan kelancaran dalam pengerjaan pembangunan gedung. Dewasa ini banyak sekali pesantren yang akhirnya membangun madrasah ataupun sekolah umum karena didukung oleh program tersebut. Ketika di desa-desa mendirikan sekolah inpres secara bersamaan mereka menjadi saingan utama bagi madrasah. Dengan biaya yang lebih terjangkau bagi warga desa sekolah inpres cenderung banyak peminatnya. Mungkin hal tersebut yang menjadi faktor utama madrasah menjadi mati dan memilih untuk dijadikan sekolah negeri (Hanipudin, 2019).

Secara literal reformasi adalah membentuk atau menata kembali. Selain itu, mengenai pengertian secara umum, zaman reformasi merupakan zaman pemerintaha yang diawali selepas jatuhnya pemerintahan pada zaman Orde Baru terjadi pada tahun 1998 (Ikhwan, 2017). Pada Tahun 1998 menjadi sebuah permulaan berdirinya reformasi pendidikan Islam di negara Indonesia. Bertepatan bersama perekonomian, sosial, dan dunia politik yang kritis menerpa negara Indonesia. Krisis yang dialami ini merupakan kerja yang giat guna mendapatkan aktivitas atau sebuah kondisi yang baik, dikenal dengan istilah masa reformasi. Menurut Emil Salim bahwa reformasi merupakan menitiberatkan terhadap transposisi bersama melihat kepentingan masa yang akan datang. Sedangkan menurut Din Syamsudin bahwa reformasi merupakan sebuah cara perbaikan yang lengkap dari orde 
kehidupan dari segi politik, ekonomi, hukum, hal terpenting pendidikan Islam (Pratama \& Zulhijra, 2019). Dari mulai tahun hingga saat ini yang sering disebut sebagai era Reformasi (Ikhwan, 2017).

Pada masa reformasi melanjutkan senuah arti yang mulia bagi kemajuan dibidang pendidikan Islam yang sebelumnya pada masa Orde Baru program pendidikannya tidak mencapai target. Perekonomian yang sedang kritis berlangsung mulai bulan Juli 1997 telah memindahkan tatanan ataupun perekonomian Nasional. Dibidang politik, zaman Orde Baru sudah saatnya berakhir dan digantikan oleh pemerintahan atau sering dijuluki sebagai sebagai "Reformasi Pembangunan" meskipun demikian Abuddin Nata, Sejarah Pendidikan Islam, (Jakarta: Kencana, 2011), hlm: 347. Kajian Sosio Historis Pendidikan Islam... - Afiful Ikhwan 16 sebagian besar jiwa zaman Orde reformasi sebagian besar jiwa tetap sedang berasal dari rezim Orde Baru namun terdapat sedikit perubahan yaitu adanya kebebasan pers dan multi partai. Membutuhkan tindakan pergeseran pola berasal dari pendidikan untuk mengatasi metode globalisasi serta kembali mengatur kehidupan masyarakat Indonesia. Membangun masyarakat madani Indonesia adalah harapan era Reformasi. Sebagian berpendapat maka reformasi telah terlaksana penanganan Negara yang telah 32 tahun berhenti, maka untuk mereka mundurnya jabatan Presiden Soeharto pada Kamis, 21 Mei tahun 1998 adalah ujung suatu kemenangan. Beberapa terdapat yang memandang zaman Reformasi untuk usaha membersihkan tindakan KKN serta hal lainnya. Sampai ekuivalen dengan pembentukan pemerintah yang bersih dan berdaulat (Ikhwan, 2017).

Reformasi hingga dapat diartikan peralihan tentang seluruh sistem pemerintah secara total. Hingga demikian, Reformasi adalah masa pemerintahan di Indonesia dimulai setelah berhentinya pemerintahan Orde Baru tahun 1998, dari tahun tersebut hingga saat ini, dinamakan era Reformasi (Ikhwan, 2017).

Pada masa orde lama perkembangan pendidikan Islam di Indonesia sangat berangkaian dengan kedudukan Departemen Agama berdiriri resmi mulai tanggal 3 Januari 1946. Departemen ini secara intens mengusahakan politik pendidikan Islam di Indonesia. Usaha tersebut diselesaikan oleh anggota khusus yang mengelola masalah pendidikan agama dengan cara spesifik. Disekolah umum, peraturan resmi pertama mencakup pendidikan agama, dicantumkan dalam UU Pendidikan tahun 1950 No. 4 dan UU Pendidikan tahun 1954 No. 20 berbunyi:

1. Di sekolah-sekolah negeri di selenggarakan pelajaran agama. Dan orang tua murid berhak menetapkan apakah anaknya mengikuti pelajaran tesebut atau tidak.

2. Cara menyelenggarakan PA di sekolah-sekolah negeri di atur melalui menteri pendidikan,pengajaran dan kebudayaan (PPK) bersama menteri agama.

Sistem pendidikan Islam sejak mendapati mutasi searah perubahan zaman serta pergantian kekuasaan di Indonesia. Pemerintah Belanda mulai mengenalkan system pendidikan formal yang lebih sistematis serta terkendali untuk memikat kaum muslimin agar masuk pada pendidikan formal, sejak Andalusia memulai berdiri dengan gerakan pembaharuan Islam, sehingga kejayaan Islam mengalami kemunduran. Hal tersebut disebabkan sistem pendidikan Islam berada di masjid ataupun langgar yang telah diperhatikan kurang memadaui dan memerlukan adanya pembaharuan dan dapat disempurnakan (Ningsih, 2015).

Perkembangan yang cukup signifikan bermula setahap demi setahap masa Oede Baru perkembangan pendidikan Islam. Madrasah serta system pendidikannya mulai didirikan diantara lembaga-lembaga pesantren. Dalam system pendidikan ini terbagi beberapa jenjang menjadi Ibtidaiyah, Tsanawiyah, dan Aliyah. Pesantren meningkat pesat dalam perkembangannya karena menghidupkan system madrasah. Tahun 1958/1959 mulai lahir Madrasah Wajib Belajar lalu memiliki hak dan kewajiban seperti sekolah negeri. Bagian dari sistem pendidikan nasional dilibatkan agar madrasah dan pedidikan keagamaan inilah tuntutan dari tokoh-tokoh Islam. Akibat pandangan sikap pemerintah yang mendiskriminasikan menjadi lebih keras dengan keluarnya Keputusan Presiden No. 34 Tahun 1972, yang kemudian diperkuat dengan Intruksi Presiden No. 15 Tahun 1974. Kepres dan Inpres ini yang isinya dianggap melemahkkan dan menjauhkan madrasah dari pendidikan nasional. Apalagi sebagian umat Islam memandang Kepres dan Inpres itu sebagai manuver untuk mengabaikan peran dan manfaat madrasah yang sejak zaman penjajahan sudah diselenggarakan umat Islam.

Timbulnya tindakan keras umat Islam dirasa oleh pemrintah yang berjalan meningkatkan kebjakan untuk melaksanakan pembinaan mutu pendidikan madrasah. Dalam hal bertujuan menangani kekhawatiran dan kecemasan umat Islam maka akan dihapuskannya sistem pendidikan madrasah sebagai kongkurensi Kepres dan Inpres di atas, maka pada tanggal 24 Maret 1975 dikeluarkan Surat Keputusan Bersama (SKB) Tiga Menteri (Menteri Agama, Menteri Pendidikan dan Kebudayaan, dan Menteri Dalam Negeri) No. 03 Tahun 1975. SKB ini merupakan acuan solusi yang di satu sisi memberikan penetapan eksistensi madrasah, dan di sisi lain memberikan kepastian akan berlanjut usaha yang mengarah pada pembentukan sistem pendidikan nasional yang integratif. Dalam SKB tersebut 
diakui terdapat tiga tingkatan madrasah yaitu Ibtidaiyah, Tsanawiyah, dan Aliyah yang ijazahnya sudah diakui sama dan setingkat dengan SD, SMP, dan SMA. Kemudian lulusannya dapat melanjutkan ke sekolah umum yang setingkat lebih tinggi, serta siswa tersebut dapat berpindah ke sekolah umum yang setingkat. Makna SKB Tiga Menteri bagi umat Islam yaitu pertama, terjadinya mobilitas sosial dan vertikal siswa-siswa madrasah yang selama ini terbatas di lembaga-lembaga pendidikan tradisional (madrasah dan pesantren), serta kedua, membuka jangka waktu kemungkinan anak-anak santri memasuki wilayah pekerjaan pada sektor modern (Yuningsih, 2015).

Dunia pendidikan Agama Islam bukan merupakan produk baru dalam kebijakan pemerintah era Reformasi. Kebijakan pemerintah pada masa reformasi ini merupakan kebijakan yang melanjutkan dari segi positif dari kebijakan-kebijakan yang telah diambil oleh pemerintah sebelum masa reformasi. Salah satu kebijakan pemerintah reformasi yang melanjutkan kebijakan pemerintah masa sebelumnya yaitu kebijakan mengenai program wajib belajar sembilan tahun yaitu jenjang SD dan SMP atau sederajat. Pada Masa Reformasi pendidikan Agama Islam lebih dilihat dan disamakan kedudukannya dengan pendidikan umum. Salah satu bukti merupakan dengan dikeluarkannya Undang-Undang Nomor 20 Tahun 2003 tentang Sistem Pendidikan nasional yang dikelola berbagai bidang pendidikan salah satunya adalah bidang Pendidikan Agama Islam yang memiliki kedudukan yang sama dengan pendidikan umum (Ikhwan, 2017).

\section{Kesimpulan}

Dapat kita simpulkan bahwa pendidikan merupakan penghubung dalam proses membimbing dan menumbuhkan kemampuan-kemampuan kemanusiaan yang baik. selain itu, pendidikan menjadi pengantar umat manusia menuju peradaban yang lebih agung atau tinggi berdasarkan pada keseimbangan jalinan manusia, lingkungan, dan Sang Pencipta. Pendidikan merupakan suatu bidang yang didalamnya mengaitkan dengan kehidupan manusia. Tujuan secara umum pendidikan Islam adalah menjadikan kepribadian setiap mukmin memiliki daya pikir yang maju, bersedia dalam melegalkan setiap kebenaran ilmunya itu, dan ahli mengimplementasikan ilmu yang dimilikinya. Tujuan pendidikan Islam dapat terwujud jika dijalankan sesuai dasar-dasar yang benar yaitu Al Quran dan Hadist.

Keadaan pada pendidikan zaman orde lama, metode yang digunakan dalam pendidikan Islam mengalami pergantian dengan zaman di negara Indonesia. Kemenangan Islam yang mengalami kemerosotan sejak jatuhnya Andalusia, saat ini yang mulai bangun dengan aksi alih generasi Islam, selain itu, pemerintahan negara Belanda juga mulai mengenalkan tentang metode pendidikan yang formal lebih terstruktur dan tertata guna menarik kaum mukmin untuk masuk pada pendidikan yang berbasis formal. Hal tersebut dikarenakan metode yang digunakan pendidikan Islam di Masjid surau sudah terlihat tidak layak dan diperlukannya sebuah inovasi baru lalu disempurnakannya. Keadaan pada pendidikan zaman orde baru, perubahan pendidikan Islam perlahan demi perlahan mengalami perubahan yang pesat, dari institusi pesantren mulai membangun madrasah. Pada tingkatan pendidikan terbagi menjadi Ibtidaiyah, Tsanawiyah, dan Aliyah. Sedangkan keadaan pendidikan orde reformasi, peraturan pemerintah masa Reformasi dunia pendidikan Islam bukan merupakan sebuah hasil yang baru. Namun, peraturan-peraturan pada zaman reformasi merupakan peraturan yang melanjutkan dari segi positif peraturan yang diambil dari sebelum masa-masa reformasi. Di antara peraturan pemerintah tersebut salah satunya adalah peraturan terkait program wajib belajar sembilan tahun yaitu tingkat Sekolah Dasar dan Sekolah Menengah Pertama atau sederajat. Oleh karena itu, pendidikan Islam sudah ada sejak zaman orde lama hingga reformasi, yang kualitas pendidikannya semakin membaik dan mengalami perubahan yang baik.

\section{Referensi}

Alidar, E. (2012). Hukum Islam Di Indonesia Pada Masa Orde Baru (1966-1997). LEGITIMASI: Jurnal Hukum Pidana Dan Politik Hukum, 1(2), 88-107. https://doi.org/10.22373/legitimasi.vli2.1429

Awwaliyah, R., \& Hasan, B. (2018). Pendidikan Islam Dalam Sistem Pendidikan Nasional. Jurnal Ilmiah DIDAKTIKA, 19(1), 34-49. https://doi.org/10.21154/cendekia.v12i1.370

Azis, R. (2019). Ilmu Pendidikan Islam (Baharuddin (ed.)). SIBUKU.

Dacholfany, M. I. (2015). Reformasi Pendidikan Islam dalam Menghadapi Era Globalisasi: Sebuah Tantangan dan Harapan. JURNAL AKADEMIKA, 20(01), 174-192.

Hanipudin, S. (2019). Pendidikan Islam di Indonesia dari Masa ke Masa. Matan : Journal of Islam and Muslim Society, 1(1), 39-53. https://doi.org/10.20884/1.matan.2019.1.1.2037

Hidayat, R. (2016). Ilmu Pendidikan Islam (C. Wijaya (ed.)). Lembaga Peduli Pengembangan Pendidikan Indonesia. http://library1.nida.ac.th/termpaper6/sd/2554/19755.pdf 
Hidayat, T., Rizal, A. S., \& Fahrudin, F. (2018). Pendidikan Dalam Perspektif Islam Dan Peranannya Dalam Membina Kepribadian Islami. Jurnal MUDARRISUNA: Media Kajian Pendidikan Agama Islam, 8(2), 218-244. https://doi.org/10.22373/jm.v8i2.3397

Ikhwan, A. (2017). Kajian Sosia-Historis Pendidikan Islam Indonesia Era Reformasi. Edukasi, 05(01), 1432. http://library1.nida.ac.th/termpaper6/sd/2554/19755.pdf

Kosim, M. (2014). Kebijakan Pendidikan Agama Islam di Sekolah pada Masa Orde Lama. Karsa, 22(1), 120. http://ejournal.stainpamekasan.ac.id/karsa/article/download/550/532

MUDZAKKIR. (2015). Pendidikan Islam Masa Orde Lama Dan Orde Baru. Jurnal Al-Fatih, 55-66.

Musanna, A. (2017). Indigenisasi Pendidikan: Rasionalitas Revitalisasi Praksis Pendidikan Ki Hadjar Dewantara. Jurnal Pendidikan Dan Kebudayaan, 2(1), 117-133. https://doi.org/10.24832/jpnk.v2i1.529

Ningsih, H. K. (2015). Perkembangan Pendidikan Islam Di Indonesia Pada Zaman Orde Lama 1945-1965. 1-15.

Nugrahani, F. (2014). Metode Penelitian Kualitatif dalam Penelitian Pendidikan Bahasa. http://ejournal.usd.ac.id/index.php/LLT\%0Ahttp://jurnal.untan.ac.id/index.php/jpdpb/article/viewFile/ 11345/10753\%0Ahttp://dx.doi.org/10.1016/j.sbspro.2015.04.758\%0Awww.iosrjournals.org

Nurkholis. (2013). Pendidikan dalam Upaya Memajukan Teknologi. Jurnal Kependidikan, 1(1), $24-44$. http://ejournal.iainpurwokerto.ac.id/index.php/jurnalkependidikan/article/download/530/473/

Pratama, P. I., \& Zulhijra. (2019). Reformasi Pendidikan Islam di Indonesia. PAI Raden Fatah, 1(1), 117127. http://library1.nida.ac.th/termpaper6/sd/2554/19755.pdf

Rahman, A. (2012). Pendidikan Agama Islam dan Pendidikan Islam - Tinjauan Epistemologi dan Isi Materi. Eksis, 8(1), 2053-2059.

Romlah. (2016). Manajemen Pendidikan Islam. Manajemen Pendidikan Islam, 1-232. https://doi.org/10.1017/CBO9781107415324.004

Sari, M., \& Asmendri. (2020). Penelitian Kepustakaan (Library Research) dalam Penelitian Pendidikan IPA. Natural Science: Jurnal Penelitian Bidang IPA Dan Pendidikan IPA, 6(1), 41-53. https://ejournal.uinib.ac.id/jurnal/index.php/naturalscience/article/view/1555/1159

Sudarmono, M. A. (2020). Tinjauan Sejarah Pendidikan Islam Masa Orde Lama . 18(1), 17-26.

Supandi, S. (2017). Interaksi Negara Dengan Dunia Pendidikan Islam Dari Masa Ke Masa. Al-Ulum : Jurnal Penelitian Dan Pemikiran Ke Islaman, 4(2), 214-227. https://doi.org/10.31102/alulum.4.2.2017.214227

Syamsuddin, M., \& Fatkhan, M. (2010). Dinamika Islam pada Masa Orde Baru. Jurnal Dakwah, XI(2), 139_ 159.

Yuningsih, H. (2015). Kebijakan Pendidikan Islam Masa Orde Baru. Jurnal Tarbiya, Volume I(Nomor 1), $175-194$.

Yusuf, M. (2018). Pengantar Ilmu Pendidikan (D. Ilham (ed.)). Kampus IAIN Palopo. 